\title{
Regulatory and Market Risk Factors and the Emissions Reduction Potential for Energy Intensive Firms ${ }^{1}$
}

\author{
Zhengfei Guan²
}

\section{Introduction}

In the last decade, one of the major global environmental concerns has been greenhouse gas emissions. As part of the political debate over climate change, various policy initiatives are being proposed. Energy intensive firms that emit large amounts of greenhouse gases (e.g., floriculture or nursery firms with heated greenhouses) will be operating in an environment of high regulatory and market uncertainties in the coming years. This article presents a brief introduction of the regulatory and market risks faced by energy intensive firms and a case study of emissions reduction potential in the horticulture industry.

\section{Regulatory Risk}

In the United States, various greenhouse gas emissions control initiatives have been proposed and debated in recent years. The Obama administration has taken a more engaging role in international negotiation, and proposed a policy that aims to reduce emissions by 17 percent over the 2005 level by 2020 and further reduce them by an additional 80 percent by 2050 (Stern 2009). The United States Environmental Protection Agency (EPA) has made a landmark ruling that greenhouse gas emissions endanger public health, enabling the government to take action against greenhouse gas emissions. In addition, Congress has made numerous policy proposals on energy issues and greenhouse gas emissions. For example, in the period from May 2009 to July 2010, when energy and emissions issues were heatedly debated, roughly 100 proposals were introduced in Congress. The proposed policies covered such issues as greenhouse gas emissions, climate, cap-andtrade, energy efficiency, renewable energy, clean energy, etc. In 2009, the US House of Representatives passed the American Clean Energy and Security Act (ACESA) aimed at reducing emissions. At the state level, governments are also pursuing policies with emissions reduction goals. For example, in 2008, the Florida Legislature passed the Florida Climate Protection Act (FCPA) (HB 7135) to control emissions, and in 2012, the Florida Legislature adopted an energy bill (HB 7117) that promotes renewable energy production and energy efficiency improvements.

Although the 2008/09 recession has slowed down the effort in pursuing greenhouse gas emissions regulation both at the federal and state level (e.g., the US Senate did not follow up on the ACESA, and the goals set by the FCPA in Florida were not pursued), once the economy is back on track and energy prices go up, the discussions on energy, emissions, and climate will heat up again and the pressure on energy and emissions-intensive industries will increase. It is expected that emissions and climate will remain one of the policy priorities in the coming years, and that the Obama administration will likely make a new push on these issues. The recent super-storm on the east coast and the scale of damage it inflicted have made more people realize that climate change needs to be treated seriously. Although there are no binding restrictions yet on most industries, including agriculture, regulatory uncertainty regarding

1. This is EDIS document FE919, a publication of the Food and Resource Economics Department, Florida Cooperative Extension Service, Institute of Food and Agricultural Sciences, University of Florida, Gainesville, FL. Published March 2013. Please visit the EDIS website at http://edis.ifas.ufl.edu.

2. Zhengfei Guan, assistant professor, University of Florida, Gulf Coast Research and Education Center, Wimauma, FL.

The Institute of Food and Agricultural Sciences (IFAS) is an Equal Opportunity Institution authorized to provide research, educational information and other services only to individuals and institutions that function with non-discrimination with respect to race, creed, color, religion, age, disability, sex, sexual orientation, marital status, national origin, political opinions or affiliations. U.S. Department of Agriculture, Cooperative Extension Service, University of Florida, IFAS, Florida A\&M University Cooperative Extension Program, and Boards of County Commissioners Cooperating. Nick T. Place, Dean 
emissions control will increase in tandem with the impacts of climate change.

\section{Market Risk}

In addition to the environmental concerns, a volatile energy market is another factor that will be driving energy intensive firms to improve their energy efficiency. In the last few years, the market has experienced unprecedented wide swings in energy prices. For example, in 2008, the crude oil price reached an historical record at $\$ 140$ per barrel before experiencing a free-fall in the subsequent recession, dropping to approximately $\$ 30$; in 2012 , the price briefly spiked to over $\$ 100$ before dropping below $\$ 80$ (Figure 1). Given the observations in recent years, energy intensive firms need to be prepared to live with a price over $\$ 100$ as the economy recovers.

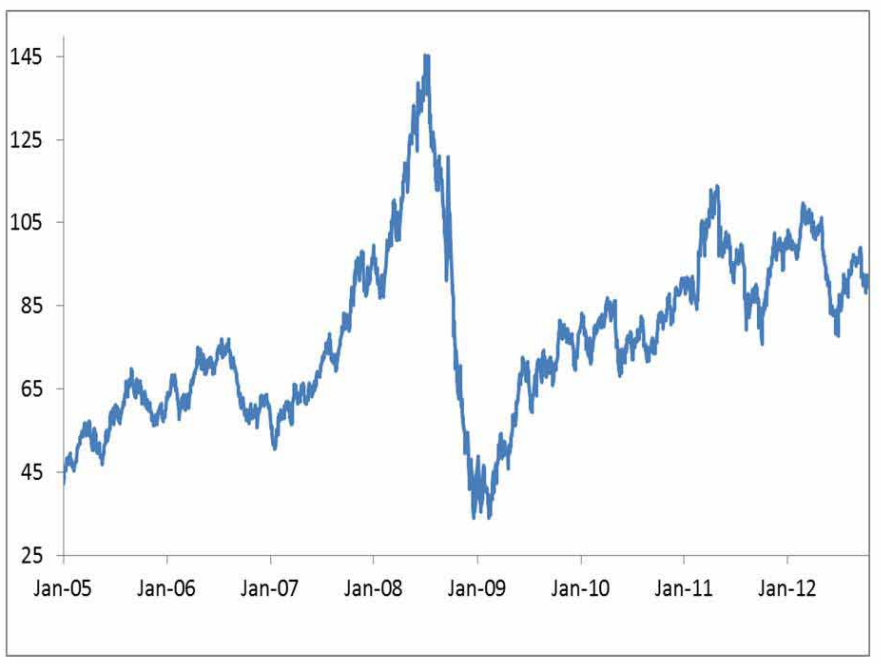

Figure 1. Crude oil price movements (USD per barrel) since 2005

High energy prices not only impact firms that use direct energy inputs, such as fuels, but also influence the market prices of major agricultural inputs, such as fertilizer and pesticides, and other materials, such as plastic films. For example, the price of urea $(44-46 \% \mathrm{~N})$ nearly tripled between 2002 and 2012, increasing from $\$ 191$ per ton in April 2002 to $\$ 554$ in March 2012 (Figure 2). High energy prices will also increase transportation costs, and therefore the cost of distribution of fresh agricultural produce.

\section{Emissions Reduction Potential of Energy Intensive Firms: A Case Study in the Horticulture Industry}

Faced with both regulatory and market risks, it is important that energy intensive firms adopt energy-efficient

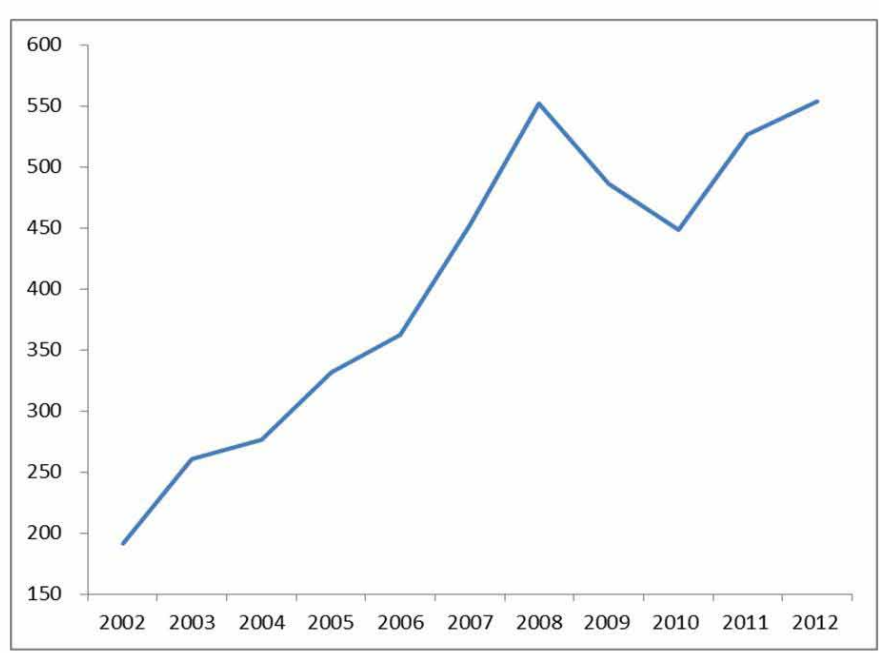

Figure 2. Urea price changes (USD per ton) since 2002

technologies to improve efficiency and reduce emissions. Although energy efficiency has been analyzed in several industries in the United States, such as the pulp and paper industry, cement industry, and transportation industry, most segments of the agricultural industries remain in queue for thorough analysis. A recent study by Guan and Gao (2012) provided an analysis of the energy and emissions reduction potential of the floriculture industry in Michigan.

Michigan is an important state in horticultural production. Its floriculture industry ranks third nationally, behind California and Florida. Its floriculture wholesale value accounts for 9 percent of the total national production, whereas Florida accounts for 21 percent (USDA/NASS 2012). The average ornamental greenhouse firm emits roughly 670 tons of carbon dioxide per season at energy costs of over $\$ 100$ thousand (Guan and Gao 2012). The efficiency analysis shows that, on average, energy consumption and greenhouse gas emissions could be cut nearly in half simultaneously if efficient technologies (e.g., central heating systems versus decentralized unit heaters) were used. The analysis also indicated that (1) there can be a tradeoff between the emissions reduction and production-cost reduction goals, and (2) firms in this study were primarily focused on costs rather than emissions control. For example, the analysis showed that growers could achieve cost reductions by using low-cost fuels that could produce more greenhouse gases. The roughly 50 percent emissions efficiency (meaning an emissions reduction potential of 50\%) is low, compared to greenhouse firms in the Netherlands, a country well-known for its strict environmental policy mandates. Specifically, the Dutch greenhouse firms had an emissions efficiency of over 70 percent (meaning an emissions reduction 
potential of 30\%) as early as the mid-1990s (Oude Lansink and Bezlepkin 2003; Oude Lansink and Silva 2003). After more than a decade of implementing strict greenhouse gas emissions policy under the Kyoto Protocol, there is likely an even bigger gap between firms in regulated and unregulated environments. The Michigan case study suggests that, in the absence of a mandatory emissions control policy, energy intensive firms are less efficient in emissions control and have large potential for energy cost savings and emissions reduction.

\section{Conclusions and Discussions}

Given the environmental policy development and high

energy market volatilities, reducing energy use and greenhouse gas emissions could improve the profitability of energy-intensive agricultural firms and reduce its exposure to regulatory and market risks. The case analysis and comparison with foreign firms operating under strict emissions regulations show that different policy environments can result in firms having significantly different efficiencies in energy use and greenhouse gas emissions, and that in an environment without emissions control, firms can achieve significant reduction in both energy cost and emissions. The implication for policy makers is that, as the focus of growers is on profitability and cost management, governments can use policy instruments, such as tax tools or subsidies, to encourage the adoption of energy saving technologies. For growers, the adoption of new technologies could result in significant savings in energy costs and potential emissions charges in the future, and it could reduce exposure to both regulatory and market risks.

\section{References}

Guan, Z., and X. Gao. 2012. Carbon policy implication for the greenhouse industry. http://ageconsearch.umn.edu/ handle/124684.

Oude Lansink, A., and I. Bezlepkin. 2003. The effect of heating technologies on $\mathrm{CO}_{2}$ and energy efficiency of Dutch greenhouse firms. Journal of Environmental Management 68:73-82.

Oude Lansink, A., and E. Silva 2003. $\mathrm{CO}_{2}$ and energy efficiency of different technologies in the Dutch glasshouse industry. Environmental and Resource Economics 24:395-407.

Stern, N. 2009. Action and Ambition for a Global Deal in Copenhagen. Centre for Climate Change Economics and Policy, Grantham Research Institute on Climate Change and the Environment, in collaboration with the United Nations Environment Programme (UNEP). http://www. unep.org/pdf/climatechange/ActionAndAmbitionForGlobalDealInCopenhagen.pdf

United States Department of Agriculture, National Agricultural Statistics Service (USDA/NASS). 2012. Floriculture Crops 2011 Summary. United States Department of Agriculture, National Agricultural Statistics Service, Washington, D.C. ISSN: 1949-0917. http://usda01.library.cornell.edu/ usda/current/FlorCrop/FlorCrop-05-31-2012.pdf 